\title{
A New Prospect for Transparent Court Judgment in China?
}

\author{
Dr. Shumei Hou, Postdoctoral Research Fellow, Griffith Asia Institute, Griffith University \\ Professor Ronald C. Keith, Department of International Business \& Asian Studies, Griffith \\ University
}

9 June 2011

\begin{abstract}
This article focuses on the understudied area of internet-facilitated judicial transparency and its implications for the right to know, the citizen's engagement with China's court system and the related development of competent legal reasoning. The analytical focus is on recent China Supreme People's Court regulations bolstering open reporting on court websites. This article explores the scope and quality of this reform, comparing it with earlier 'open trial' initiatives and investigating its origins in its contemporary implications both in terms of generating public confidence in fair trial and in furthering the development of legal education inside and outside of the legal system. The internet may help to circulate an improved legal reasoning within the judiciary as well as support a more informed public understanding of the law's requirements. Openness may pressure judges into a wider process of research and learning as they are more exposed to public scrutiny. At the same time it may well expose the extant level of legal incompetence in China's new legal system.
\end{abstract}

Key words

China; judicial transparency; open trial, judgment 


\section{Introduction}

Lord Chief Justice Hewart's famous 1924 aphorism, 'justice should not only be done, but should manifestly and undoubtedly be seen to be done', has made its way around the world as a recommendation for judicial transparency. ${ }^{1}$ This aphorism even has some qualified resonance in contemporary China where transparency is seen as supporting modern rational governance, clean government and open public administration against injustice and the corruption of power. At the 17 National Congress, 15 October $2007 \mathrm{Hu}$ Jintao, for example, endorsed 'transparency' as a means of 'enhancing the people's trust in Government' saying: 'Power must be exercised in the sunshine to ensure that it is exercised correctly. ${ }^{2}$ Several weeks later Luo Gan(罗干) gave a speech as the Chairman of the Party's Political and Legal Affairs Committee. Drawing on Hu's $17^{\text {th }}$ National Congress report, Luo attacked Western style ‘judicial independence' and called for Party leadership over the 'political-legal system' (政法系统) ${ }^{3}$ Were Hu and Luo in contradiction? Or is it possible to advocate and implement transparency within China's political-legal system? These questions inform this article's discussion of the new generation of China Supreme People's Court (SPC) regulations supporting judicial transparency.

There is a relevant vibrant scholarly literature on the development of China's courts. ${ }^{4}$ However, judicial transparency has only in the last few years become a prioritized issue in Chinese judicial reform. It is important on at least two related counts. Firstly, it is part of a citizen's basic "right to know” (知情权), whether the court has fairly and professionally handled specific charges in its proceedings. The adage that 'justice must be seen to be done' may have some application to China as Party-led reform has been concerned with the wider public resort to, and acceptance of, legal processes as legitimate, especially in a context of general concern over fairness and corruption spreading into the legal system, itself. Secondly, access to court decision-making may help support increasing competence within China's legal circles, whose education in law is then enhanced with clarified knowledge of the actual comparative application of the law. Better education can facilitate informed citizen response to the legal system, and it might well mean better due process. Ultimately transparency supports the essential operation of the rule of law. In her definition of 'transparency', for example, Sarah Biddulph, put it succinctly, 'The first aspect of transparency involves being able to know what the law is and expecting that it will be enforced according to its terms. ${ }^{5}$ 
The Transparency International Corruption Perceptions Index currently ranks China as seventyeighth of 178 monitored states. ${ }^{6}$ China's many critics are not likely to be impressed either with this ranking or Hu Jintao's assurances that the Chinese government's commitment to transparency is real. They will underscore the unqualified and immediate relation between law and politics which makes any semblance of judicial independence extraordinarily difficult, if not impossible. ${ }^{7}$ Simply, it is assumed that in China there is a basic structural resistance in the one Party-State to transparent justice. The prospects for transparent judicial judgment within China's particular 'political-legal system' came under strong international criticism in light of a series of controversial trials in 20092010, including the trials of British citizen, Akmal Shaihk and Nobel Prize Recipient, Liu Xiaobo. ${ }^{8}$

Open trial and related accessibility to court judgment is certainly a serious concern to foreigners living and investing in China. Foreign media coverage of the trial of Rio's executive, Stern Hu, characterized the rule of law in China as 'hollow'. Then Prime Minister Kevin Rudd of Australia commented on the closed part of Rio Tinto Executive Stern Hu's trial proceedings concerning 'commercial secrets': 'China, I believe, has missed an opportunity to demonstrate to the world at large transparency that would be consistent with its emerging global role. 9

The study of recent regulation on judicial transparency and its impact on legal competence and public trust is inevitably connected to the wider discussion of the rule of law and judicial independence, and it would seem that the Chinese, themselves, have confirmed the views of their critics. The current President of the SPC, Wang Shengjun, re-affirmed the close relationship between politics and law, commenting in 2009 in the Guangming Ribao (光明日报): ‘Judicial power as an important ruling power is a significant way for the Party and the people under its leadership to administer state and social affairs. ${ }^{, 10}$ Taking another cue from the Party, Wang cast doubt on China's commitment to the 'supremacy of law' and affirmed the SPC's interest in the stronger assertion of 'Chinese characteristics'（中国特色的）in the court system; and energetically endorsed the 'three supremes', (三个至上) namely, supremacy of the Party's cause, supremacy of the people's rights and interests and supremacy of the laws and constitution.

The former Dean of Peking Law School published a well considered, but trenchant article in the Yale Law Journal objecting to the failed methodology and ideologically inspired observations of 
China's judiciary in foreign China law scholarship and reporting. In setting the record straight, Zhu Suli objected to 'presuppositions' that a) there is 'a unique political influence that comes from the $\mathrm{CCP}$ ' and b) 'that it is possible to create a standard model of a judiciary from political influence' and c ) that it is possible and necessary for researchers to examine and measure independently such influence.' Professor Zhu observed that the Party's influence is 'ubiquitous at every level and in every aspect of contemporary Chinese society', but that its influence on the judiciary is 'general and diffuse'. Zhu pointed out that CCP organization principles are in 'conflict with the operation of professional logic' but they are 'in concert with China's social development.' He candidly addressed the question of judicial independence and Party interference in China's judiciary:

Today, although the CCP has adopted "relying on the law to rule the country" (依法治国) and judicial independence is inscribed in the Constitution, party organizations and individuals persist in influencing and interfering with the judiciary. However, although these interferers are sometimes leading cadres who "wave the flag" of the local Party organization, it does not mean that this individual's interference represents the Party's or that particular Party organization's interference. To the contrary, some of them are violating CCP principles, policies and disciplinary rules. ${ }^{11}$

In his introduction to the first English book on China's judicial independence, Randall Peerenboom notes that China 'outscores the average country in its income class, including many democracies, on many rule of law and good governance indicators' and suggests that as a model for developing countries China 'challenges key assumptions of the multibillion-dollar rule of law promotion industry'. ${ }^{12}$ Referring to the 'most basic form of judicial independence' as 'the ability of judges to cases independently in accordance with law and without...interference from other parties or entities', Peerenboom is naturally sympathetic to Zhu Suli's argument that the concept of judicial independence is not clear and that there is no one agreed upon model, but he adds that China's judges are able to decide most cases independently and that this generalization is especially valid for commercial cases. ${ }^{13}$

Liu Guixiang, President of the No. 4 Civil Court of the Supreme People's Court of the People's 
Republic of China (SPC) may have indirectly responded to Prime Minister Rudd's gloomy observation commenting on how China protects the 'legitimate rights of litigants from home and abroad.' Liu confirmed that in a 15 per cent increase over the previous period, 13,191 foreignerrelated cases went before 167 intermediate and 67 district courts from January through November 2010. Ninety-six per cent of these cases concerned civil and commercial cases that commonly related to foreign stocks, bonds, notes, credits, the dissolution and liquidation of foreign-funded enterprise and related investment undertakings. Liu was pleased to report: 'Almost all the cases were heard in public, and we published the verdicts online as a major way to eliminate local protectionism. ${ }^{14}$

The controversy over Chinese 'judicial independence' is likely to continue. Judicial transparency, however, is important to 'justice has been seen to be done', and it recently it appears to be achieving some degree of traction in actual court behavior particularly in the context of the developing new information order inside China. Benjamin Liebman, Tim Wu and Donald Clark have noted that in the context of developing conflict with the media and other institutions China's judges in deciding cases are increasingly engaging in 'horizontal' consultation with other judges and also with members of the public and academics rather than simply relying on vertical consultation with political authorities. ${ }^{15}$ This raises the possibility of more informed and better researched judgments.

The internet is filliping the transmission of legal information in China, and Clark and Wu suggest that 'horizontal' engagement may help overcome the lack of a system of precedent and may generate public trust. They noted: 'Courts and legal systems that treat like cases alike would appear both more deserving of and more likely to receive public trust. ${ }^{16}$ They are also counterintuitive in their proposition that, as China's court system is more influenced by public opinion than in the US and Europe, the impact of the internet may actually be far greater than in China. ${ }^{17}$ They also advise that, while internet judicial transparency might foster citizenship, it may also precipitate an 'information cascade' that overwhelms judges' impartial interpretation of the law. ${ }^{18}$

To be sure, China's now very large legal system is new and the level of court competence is still modest. Writing in 2005, Jean-Pierre Cabestan noted the lack of qualified personnel throughout China's legal system and made the following prediction: 
This is the avowed reason why most the judicial awards made by the courts are not published: many of them do not even end up in written form while the written judgments are often far from comprehensive or up to the legal standards required by the Supreme Court. Thus, despite the WTO commitments, the lack of expertise will contribute for a long time to keeping court decisions are least partly secret when they only concern Chinese nationals. ${ }^{19}$

Fan Wu in a more recent 2009 study asserted that the 'lack of legal reasoning' goes so far as to state categorically: '...it can be concluded that legal reasoning is close to absent both in Chinese jurisdiction and legal education. ${ }^{20}$

The first local regulations on transparency appeared in China in $1987,{ }^{21}$ but even before the Chinese characters for 'transparency' (透明) first appeared there was an interesting history pertaining to the notion of 'open trial' that serves as an important contextual reference point for judicial transparency as it is spreading in today's new information context.

Making court judgment publicly available in the context of China's new information order is now a key issue in the Chinese judicial reform. This article discusses the development of a Chinese notion of "transparency" in light of the historical record and the changing dimensions of open trial as China moved from Mao's era into the reform era of Deng Xiaoping and Jiang Zemin and through to the contemporary regulatory initiatives in the new information age under Hu Jintao. With reference to a new generation of SPC regulation on openness, the analysis begins to probe the prospect for institutionalizing the right to know so as to support an emerging relation between judicial transparency and legal reasoning.

\section{Historical Background}

China's extraordinarily long and complex bureaucratic tradition instinctively regarded knowledge as power. The controlling of information by 'parent officials' (父母官) was a matter of 
refined state administrative technique. ${ }^{22}$ In the paternalistic context of imperial rule, the Emperor's subjects were not viewed as rights-bearing citizens. ${ }^{23}$ The citizen's 'right to know' was not needed to correct government. The law existed only to maintain the moral legitimacy of the state and to enhance dynastic control over society. ${ }^{24}$ The Emperor's subjects were not endowed with independent reasoning. In the instance of profligate imperial immorality they could explode with indignant rage, but this was a reflection of cosmological disorder that merely heralded dynastic decline. Moreover, the Emperor's officials were evasive in reporting popular discontent. Honest reporting could invite nervous imperial investigation and possible punishment for failed performance.

This was the bureaucratic legacy that was bequeathed to the Chinese Communist Party $(\mathrm{CCP})$ in 1949. The CCP disavowed the shortcomings of the imperial tradition calling for mass activism in opposition to ‘bureaucratism’ (官僚主义). As Professor Stuart Schram has argued, the Party’s notion of mass line politics represented a 'rupture with one of the central themes of traditional thought.' The people then became the 'source of good ideas from which correct policies are elaborated.' The Party disagreed with the Confucian Analects that had asserted: 'The people may be made to follow a path of action, but they may not be made to understand it. ${ }^{, 25}$

Not only did the people provide ideas, but they were to participate in the supervision of the state. The mass line was premised in a theory of knowledge that 'scientifically' combined the general with the particular. This viewpoint presumed that the 'scientific methods of leadership' would enhance the Party's real links with the masses in opposition to 'bureaucratic and subjectivist methods of leadership'. ${ }^{26}$ Mao, however, supported Confucius on one key point: 'We should never pretend to know what we don't know, we should not feel ashamed to ask and learn from people below. [from the Confucian Analects], ....To do this will not lower one's prestige; it can raise it. ${ }^{27}$ Ideally, Mao's mass line encouraged an honest work style that built on open criticism and self-criticism and the reporting of both good and bad news at all levels of government.

Does this revolutionary experience and thinking have contemporary relevance? Transparency per se was never an issue in imperial China, but there was qualified support in the post-1949 mass line of the Communist Party for the later acceptance of incipient 'transparency' as politically expedient and necessary to open public administration. In the 1990s Jiang Zemin formulated a thesis 
on how political parties lose power--a thesis on 'rise and fall.' An honest style of government has always been an important factor for popular support, good government, and the stability and prosperity of society.' Jiang criticized bad cadres who came out when the sun was not shinning and regarded their position, influence and conditions as their own 'vested interests' even taking 'these things as private property. ${ }^{28}$

Hu Jintao has specifically endorsed 'transparency' especially in the light of the transition from the revolutionary party of the 1950 s to today's 'ruling Party'. Referring to the complexities of a new economic world that was witnessing an explosion in information technology, $\mathrm{Hu}$ acclaimed a new trend towards modern public administration, and he related cadre workstyle (工作作风) to the importance of open communications to facilitate better policy development and application. While $\mathrm{Hu}$ Jintao is certainly no friend of liberal democracy, he advocated 'transparency' as means of supporting the people's knowledge and participation in good governance. His October 2007 report to the $17^{\text {th }}$ National Party Congress affirmed:

Power must be exercised in the sunshine to ensure that it is exercised correctly...We will improve organic laws and rules of procedure to ensure that state organs exercise their powers and perform their functions and responsibilities within their statutory jurisdiction....We will improve the open administrative system... and increase transparency in government work thus enhancing the people's confidence in government.

The December 2010 white paper on corruption and clean government" followed up on this reasoning: 'As sunshine is the best antiseptic, transparency represents the best supervision of power.' The White Paper stressed that '...government information...should be made public in a timely and accurate matter with the requirement of making public as the principle and holding back as the exception, to guarantee the people's right to know, participate, express and supervise. ${ }^{29}$ The White paper, however, placed China's courts within a Party-led 'supervisory system with Chinese characteristics' that features 'both restraint and coordination among decision-making power, executive power and supervisory power to promote procedural power exercise[s] featuring transparency.... ${ }^{, 30}$

\section{The Changing Dynamics of Open Trial and Judicial Transparency}

Notion of open trial is much older than "judicial transparency", and it has served different and sometimes dubious political purposes. The notion of open trial antedates the current subscription to 
'transparency'. In the early 1950s, however, open trial emphasized the importance of mass education in the context of suppressing "bad elements". Openness was purposefully used to consolidate New China by raising the consciousness of the wronged masses, who were struggling against their oppressors. The law was to be clear and easily understood by the masses who wanted retributive justice. The earliest gesture towards open trial policy was made in 1950 when the Northeast People's Justice Ministry required that the people's court open its trials to the people so as to raise their level of political consciousness ${ }^{31}$ However, the law and the legal system were in exceptionally weak state when they were aggressively subordinated to the politics of large-scale mass mobilization. Undue subscription to due process was easily conceived as throwing cold water on the masses who demanded justice; and it could very well lead to accusations of siding with the class enemy.

However, the 1954 Constitutional Law heralded a new stage of formal legal development when it affirmed: '...except in special circumstances as specified by law, all cases in the people's courts are heard in public.' The same principle was reiterated in the 1978 and 1982 state constitutions.

The Chinese courts had tentatively started to open trials to the public so as to educate people with the legal knowledge when this initiative was abruptly abandoned in the blaze of legal nihilism and popular justice during the Cultural Revolution. The Party leadership was traumatized in the Cultural Revolution. The post-1978 reforms of Deng Xiaoping laid the groundwork for an authentic legal reform that was to help contain the wild antics of the Cultural Revolutionary era when judges and part-time lawyers could be arbitrarily held to account as the 'enemies of the people.' Openness was no longer to serve the hunt for the class enemy. The legal system had no longer to contend with the demands of large-scale mass mobilization, but the court system still had to be built up, and both the officials and the people had to learn 'to act according to law.' New procedural exercises had to be put in place and practiced. The 1982 Constitutional Law essentially looked forward to open trials, but the conditions for the realization of such openness were still politically and organizationally premature.

With Deng Xiaoping's legal reforms professionalism acquired more priority, but even now, after SPC President Xiao Yang's reforms of 1999-2008, judges still have difficulty constructing sophisticated legal reasoning. Traditionally, judges were more inclined to instruct rather than to 
reason. Arguably, support for openness requires relatively autonomous capacity as well as confidently applied judicial competence. Judicial reform was given new priority in the political reforms discussed at the $15^{\text {th }}$ National Congress of the Communist Party of China held in $1997 .^{32}$ Then Minister of Justice Xiao Yang, in commenting on China Central Television's 11 July, 1998 live broadcast of a civil suit, believed that open trials increase judicial openness, prevent 'darkroom operations,' and see to it that 'justice is served. ${ }^{33}$ Openness was placed in opposition to corruption. Public justice was in some sense freed from the burden of class struggle but the Party continuously sought to assuage the anger of the masses (民愤).

In the early 1990s, the SPC began to set out regulations requiring people's courts to conduct open trials. In October '1998, the Supreme People's Procuratorate(SPP) decided to open all trials to the public. ${ }^{34}$ In 1999, the SPC issued Several Provisions on the Strict Implementation of the Public Hearing System (最高人民法院关于严格执行公开审判制度的若干规定), clarifying that the pronouncement of judgment, (as part of court hearings), should be made public as well, and provided that all judgments shall be published. ${ }^{35}$ Also, for the first time, the SPC stressed in this Provision that citizen could gain admittance to court hearings by showing their identification. ${ }^{36}$

Western observers extolled the virtues of transparency at the time of China's entry in to the WTO. China's WTO membership was widely expected to open up Chinese state administration, but there was an even more politically important breakthrough in domestic political thinking about Party legitimacy and public accountability that came with the initial SARS crisis. Caught off guard by local failure to report on the seriousness of the outbreak the new leadership of Hu Jintao rediscovered the mass-line importance of opening the channels of communication that could help deal with the mounting contradictions in Chinese society. ${ }^{37}$

The September 2004 CCP Central Committee decision on Party governance reflected a new learning curve in Party leadership. The Decision chastised local cadres for their failure to uphold the mass-line work style of honest reporting, and called for opening 'the channels by which the state of society and public opinion are reflected:'

Establish a mechanism for collecting and analysing the state of society, and clear the channels by which the state of society and public opinion are reflected. Establish a social early warning structure 
and put it on a sound basis, for a contingency mechanism and unified command, a wide range of functions, agile reaction, and highly effective operation, and enhance the ability to ensure public safety and deal with sudden incidents. ${ }^{38}$

Indeed the SARS experience eventually resulted in a new leadership focus on the management of "sudden incidents" and the importance of transparent public administration. Hu Jintao attempted to update the formal dimensions of mass-line work style that called for honest reporting to support changes to policies in changing conditions and to ensure "a social early warning structure."

The 2005 White Paper on the building of political democracy in China endorsed judicial democracy' as it includes 'trial by levels, challenge, open trial, people's jurors, people's supervisors, lawyers, legal assistance and people's mediation' so as 'to guarantee the democratic rights of the people and the legitimate rights and interests of citizens.' The White Paper may have been asserting an ideal condition when it commented on the constitutive elements of 'open trial':

...the Supreme People's Court requires courts at all levels to try cases openly and in strict accordance with the law, in open courts and with evidence openly submitted, question the witnesses openly, and announce all judgments openly. The people's courts at various levels have further reinforced the system of open trials. .... Notice of cases to be tried in public shall be announced in advance to open the entire process to the auditing of ordinary citizens and the press. The people's courts also, on their own initiative, invite deputies to the people's congresses and members of Chinese People's Political Consultative Conference (CPPCC) organizations to audit open trials so that the National People's Congress deputies can supervise and the CPPCC members can inspect judicial activities. ${ }^{39}$

At the $17^{\text {th }}$ National Party Congress, in October 2007, Hu correlated 'transparency' with stepped up 'education about citizenship.' Informed citizenship was supposed to foster 'political consultation, democratic oversight, and participation in the deliberation and administration of state affairs. ${ }^{40}$ Picking up on the 'scientific development' (科学发展) elements of mass-line notions of leadership, $\mathrm{Hu}$ promised: 'To ensure scientific and democratic decision-making, we will improve the information and intellectual support for it, increase its transparency and expand public participation in it.' Hu underlined the need to '...improve the mechanism of restraint and oversight and ensure that power entrusted by the people is always exercised in their interests. Power must be exercised in the sunshine to ensure that it is exercised correctly.' Thus 'transparency' entered the Party's vocabulary as necessary to China's 'open administrative system. ${ }^{41}$ 


\section{The Opaque Limits of Openness}

This was the changing wider political context that informed a 2005 debate between scholars He Weifang (贺卫方) and $\mathrm{Hu}$ Xiabing (胡夏冰) in the Legal Daily (法制日报) over the appropriate scope of transparent court judgment on the internet. He Weifang waxed with enthusiasm. He believed that judicial power, as one of the most important components of state power, must be disclosed to the public and also that it should be placed under the people's supervision. Therefore, the SPC and local courts must render all of their legal documents transparent to citizens (excluding the familiar stipulated categories of documents relating to state secrets, personal privacy, and juveniles). ${ }^{42}$

Hu Xiabing was deliberately qualified, arguing that one of the key purposes of judgment transparency is to establish the case guiding system so as to ensure that judges apply the laws uniformly throughout China, thus improving the dignity and authority of the country's judicial system. In his view, only the cases identified by the SPC need to made transparent. ${ }^{43}$ Hu worried that unrestricted transparent reporting of all cases could create public confusion as judges make different judgments using the same laws whereas the leading cases have been carefully filtered through a selective process of SPC research and analysis designed to promote consistent national understanding. ${ }^{4}$

At the time, the $\mathrm{CCP}$ was becoming increasingly alarmed over surging judicial corruption ${ }^{45}$ and the growing case overload ${ }^{46}$ in a slow-moving judicial system that denied justice to the angry frustrated masses, many of whom were the victims rather than the beneficiaries of economic reform. The system needed immediate sunshine. The optics of judicial corruption was politically intolerable, especially when the Party had so emphatically re-dedicated itself to meeting the people's needs.

The Party moved in 2007 to ensure public confidence in the judicial system. It wanted to show that it could deliver justice in real time. Efficiency counted for more than professionalism. The latter slowed down the system. Mass line thinking and work-style underwrote 'judicial democracy' (司法 民主). The courts needed to deliver justice and to respect the 'feelings of the people,' in a time when there is growing sense of public outrage over corruption as well as a sense of relative deprivation and 
rising inequality on the part of those who were increasingly marginalized in the new socio-economic context of market property relations. The Party required 'justice for the people' (公正为民). The masses were pounding on the SPC's doors to present their petitions of grievance. The Party told the courts to take up the 'two musts,' namely, they must fight corruption and they must meet the 'people's needs'.

In 2007, the SPC responded issuing Several Provisions on the Enhancement of Public Trial at the People's Court（关于人民法院审判公开工作的若干意见）. For the first time, this SPC judicial interpretation set out three principles of open trial, namely, open trial according to law, open trial without delay, and open trial in all respects. ${ }^{47}$ Court decisions were part of an education process that was to pacify outraged public opinion. This was particularly true of high profile cases involving criminal violence. Decisions regarding intellectual property, for example, attracted less general public outrage but they could still generate heated antagonism among the parties involved. Issues of "social welfare", on the other hand, have generated a widespread sense of injustice and this has helped to precipitate a re-writing of laws concerning public interest as the justification for real estate development.

\section{Coping with the New Judicial Information Order}

Since 1982 there has been extraordinary institutional development in the legal system, including

the crash professional training of new generations of qualified judges and lawyers. ${ }^{48}$ The early reform decades of training and institutional development provided a new, if not altogether sturdy basis for returning to an agenda of open trials. The SPC had already adopted the practice of selecting SPC and local court judgments and publishing them in its flagship Gazette. This official journal is monthly case-studies publication designed for judges, lawyers, legal researchers and citizens to study legal cases. Seventy-one volumes of the 人民法院案例选 (Case law of the people's courts) since 1991.There are monographs and case-related books in almost all legal fields. This form of education would then support the uniform application of the law in the courts.

However, according to the SPC's own survey in 2008, only $2.28 \%$ of the Gazette readership consists of students, even less $(1.85 \%)$ of legal education and research professionals. ${ }^{49}$ An improved, 
informed wider readership might follow in the event of a transparency reform that includes detailed information concerning the judgment-making process involving judges' different opinions, senior judges' suggestions and legal committee's decisions. Indeed Chinese citizens had lodged petitions calling for this type of qualitative reform.

In 2009, the SPC issued another two judicial interpretations, Several Opinions on the Further Strengthening of Judicial Work to Serve the People (关于进一步加强司法便民工作的若干意见) and Several Opinions on the Further Strengthening of the Work of Opening the Channels of Popular Communication (关于进一步加强民意沟通工作的意见). These interpretations suggested a sense of renewed public policy purpose in bringing about an open trial system. On 8 December 2009, the SPC issued the Six Requirements of Open Justice (司法公开的六项规定) and required the People's Court at every level to collect its judgments, publicize the court verdicts online and to broadcast live court trials over the Internet. ${ }^{50}$ The new requirements came with the standard caveat that cases involving national secrets, juveniles, personal privacy and mediation cases would not be publicized, but it was, nonetheless, extraordinary commitment to make for a large developing state under Communist leadership. The SPC's work report to the National People's Congress (NPC) on 11 March 2010 assigned top priority to judicial openness and judicial democracy.

\section{Open Trial and the Impact of the Internet}

In his study of modern court systems, Wim Voermans discusses how the new information age was impacting the courts in the West:

Transparent proceedings serve a variety of goals, one of them the possibility to exercise some form of control over the judiciary. Nowadays, however, the need for public administration is not satisfied by mere open trials. Judicial activities have accessed the centre stage of public debate, televised mass media serve as intermediaries, and we live in an information age where information is exchanged with lightning speed. This affects both the way courts provide information and the level of public expectation. $^{51}$

The court use of the internet is spreading in China. Many local courts have formally accepted citizen 'supervision' and have placed their judgments on the internet. Since 2008, the High Court of Henan Province published $97.97 \%$ of its judgments on the internet. ${ }^{52}$ In this particular case, the High Court boldly posted both the 'best' and 'worst' judgments on the web. The 'worst' judgment was an 
11 May 2010 civil judgment made by the Anyang City Longan District People's Court on a question of child custody. ${ }^{53}$

The survey reportedly had a salutary effect. After the Henan High Court introduced on-line judgments the province's rate of people's grievances to the SPC dropped from the third to eighth place in the country. ${ }^{54}$ Presently, of those courts that are authorized to deal with foreigners, every high court (32 high courts in China), 97 out of the 409 intermediate courts and 472 out of the 3117 basic courts have established websites to make their judgments available on the internet. ${ }^{55}$

The leadership of the Henan High Court has been trying to make a name for itself fostering transparent legal proceedings on the basis of a mass-line work-style. This is suggested in the unfolding of the recent case of Shi Jianfeng who was given a life sentence by the Pingdingshan (平 顶山) Intermediate Court for embezzling 3.68 million Yuan from the road toll system. Shi had bribed People's Liberation Army (PLA) personnel so that he could transport his goods in a PLA truck with a PLA licence thus evading the road toll over eight months. Once the case was posted on the web, there was a whirlwind of media coverage and internet coverage. ${ }^{56}$ The masses, however, were more agitated by the confirmation of such high road tolls than by Shi's criminal ingenuity. The High Court proclaimed that it was not afraid of revealing mistakes in the lower court system, and it disciplined the panel of three judges who sat on the original case in the Intermediate Court. Apparently, these judges had failed to uphold a proper evidentiary standard and had failed to establish the facts. ${ }^{57}$ Court transparency had an unintended consequence in the court of local public opinion. Public outcry over inappropriately high rates of road toll fixed political attention on corruption and resulted in a high priority provincial investigation. ${ }^{58}$

At its official website, http://www.cout.gov.cn, the SPC now publishes almost all of its own judgments. There are still challenges to accessibility. The China Law Info Database at Peking University carries selected court judgments but this is a limited fee-for-service arrangement. ${ }^{59}$ The court websites often carry the same information, but the courts provide truncated reporting on legal reasoning, and there is currently no hyperlink search option to facilitate deeper research across the legal findings of similar cases. 
The SPC issued a second key judicial interpretation, The Model Court Standard for Judicial Openness (司法公开示范法院标准) on 20 October 2010. This interpretation authorized a program of statistical monitoring, setting up a 100 point scale to measure the court-judgment transparency. ${ }^{60} \mathrm{~A}$ condensed version of this system is provided below in English translation.

\begin{tabular}{|l|l|}
\hline Points ( total 100) & \multicolumn{1}{|c|}{ Open Court Standard } \\
\hline 15 points & The court opened case -registration procedure to the public \\
\hline 15 points & The court opened trial procedure to the public \\
\hline 10 points & $\begin{array}{l}\text { The court opened judgment enforcement procedure to the } \\
\text { public }\end{array}$ \\
\hline 10 points & $\begin{array}{l}\text { The court opened court hearing procedure to the public } \\
\text { available on the internet and set up a monitoring system to } \\
\text { look after its website. }\end{array}$ \\
\hline 10 points & $\begin{array}{l}\text { The court published the court procedure guidelines on-line } \\
\text { or other media. }\end{array}$ \\
\hline
\end{tabular}

At least some of the categories overlap, and one wonders whether this kind of box ticking makes qualitative allowance for different conditions and different base lines of institutional development and budgetary allocation, especially in relation to the weakness of the rural judicial infrastructure. Moreover, after the first round of national monitoring of local courts below the SPC, one hundred local courts were acclaimed as model open courts. ${ }^{61}$ There are over 3558 local courts below the SPC. ${ }^{62}$ Even given that the system has just started up, this is perhaps a rather low level of successful performance.

Past declarations on open trials were not followed up with entirely convincing patterns of consistent publication. The recent push for open trials has, however, received more priority in practice than ever before. Open court judgments promise several important benefits including the 
casting of more sunshine on judicial corruption, enhancing popular awareness of the law and reduction of unnecessary lawsuits. Zhang Qiang in Henan Province, for instance, was acclaimed for withdrawing his lawsuit after reading an online judgment. Once he understood the underlying concepts behind the court's judgment he apparently realized that there would be no purpose in further legal action. ${ }^{63}$

\section{Legal Reasoning}

The quality of judgment 'openness' varies with the type and significance of the information disclosed. The most critical element in this regard is the disclosure of the judge's legal reasons for judgment, or 'legal reasoning'. The latter is an essential component of rule of law, as it ensures that opinions are administrated 'fairly, rationally, predictably, consistently and impartially. ${ }^{64}$.Legal reasoning will significantly increase the quality of judicial opinions, which will raise the public's respect for and trust in the legal system. ${ }^{65}$ This is not only key to the development of competent legal reasoning but it is also a matter of satisfying public enquiry, thus it relates to the legitimacy of the court system and the government. Analysis, however, has also to consider the extent to which savvy judges might exploit the reasoning section of their judgments as a kind of "razzle dazzle" to cover over corruption before a public that is not well versed in the fine points of law. . ${ }^{66}$ Moreover clients may well seek out lawyers that have personal relations with judges who "function within a culture plagued by corruption. ${ }^{, 67}$ Indeed vested interests may not find on-line reasoning as very congenial at all.

The PRC's court system is relatively young. The trial system has been through successive periods of traumatic political turmoil. In the past too much focus on procedural justice was taken as a hostile attempt to cool the ardor of masses seeking popular justice. Even today, there is a public sensitivity to "golden lawyers" getting notorious criminals off on the basis of technicalities. For a very long time procedural law has languished in the shadow of substantive criminal law. This also explains the comparative weakness of Criminal Procedural Law despite the concentrated focus on professional standards during the ten-year tenure of SPC Court President Xiao Yang. 
If the tension between mass-line populism and professionalism is still not resolved in today's legal system, the current focus on open trial appears as more convincing. This begs the question as to the quality and type of information that is made open. Legal reasoning has been a weak point in court judgment. It tends to be terse and sometimes non-existent. As one Supreme People's Court judge told the authors, legal reasoning in a Continental tradition involves a less developed statement of reasoning than in the American case-law tradition. ${ }^{68}$ Certainly, a condensed summation of legal reasoning would be preferred in the Chinese case where the Civil Law tradition has had some influence and where "judicial democracy," as it is inspired by traditional mass-line populism, requires the law to be clear enough to be understood by the masses.

The SPC has a strategy of rationalization or regularization so that judicial decisions are clear and open to the public. Wide openness as to the legal reasoning of judges can, however, reveal a plethora of mistakes, too many of which could serve to discredit a judiciary that has been weakened by charges of corruption. On the other hand, once a real institutional commitment to extended and transparent legal reasoning is made, it may create a rolling pressure, or an organizational incentive so that judges will take greater care in drafting reasoning that will appear on the internet. Face and career are sometimes on the line. The more a given case is made open, the harder judges will have to work to maintain their public standing and the legitimacy of the judicial system.

Professor Fan Wu has asserted that legal reasoning is not a 'common phenomenon' in China. ${ }^{69}$ He agrees with Professor Hongju Ma's assumption that in '...civil law countries, legal writing and legal drafting are taught more in the practice than at college. ${ }^{70}$ Law schools tend to teach knowledge rather than skills. Turning to China's SPC, however, it has accepted its responsibility to lift the game of the entire court system so as to ensure an appropriately professional standard of judgment. This process also includes routine mass-line education whereby senior judges are expected regularly to participate in the education of younger judges at the lower levels.

\section{Style Template of Judgment}

In 1992 the SPC initiated a program to rationalize the standards of judgment in 1992 issuing the Style Template for the Procedural Litigation Documents of the Court (法院诉公文书样式). In 1999 
and 2004 the SPC again acted, issuing two judicial interpretations, The Style Template of the Criminal Law Judgment of the Court (法院刑事诉讼文书样式) and the First Instance Judgment of the Administrative Law Judgments (一审行政判决书样式). Furthermore SPC regulations, in its Second Five Year Reform Outline (人民法院第二个五年改革纲要) addressed the standard of judgment requiring that judges improve their professional skills, especially with regard to their legal writing and legal reasoning skills, and their careful sifting of the evidence.

The new SPC strategy to improve the standard of judgment focused attention on five essential parts. ${ }^{71}$ The first part is the Introduction (首部), which includes the title of the judgment and case number, the general history, and a summary of the parties' complaints and defenses. The second part is facts (事实). It includes parties’ evidence (举证) ; cross-examination (质证) ; authenticating the evidence ( 论证 ) ; and the summary of facts (事实叙述). The third part is the reasoning (理 由 ). The fourth part is the judgment result (判决结果). The last part is the Conclusion (尾部). ${ }^{72}$ The following charted case is a typical example of a simple 'leading case' (案件指导) that originated with the Intermediate People's Court of Qiqihar. The following chart reflects the standard division of judgment into five parts. ${ }^{73}$

\begin{tabular}{|c|c|}
\hline $\begin{array}{l}\text { Part One: } \\
\text { Introduction } \\
\text { ( 首部 ) } \\
\text { 1.title of the } \\
\text { court and } \\
\text { case number }\end{array}$ & $\begin{array}{l}\text { The Intermediate People's Court of Qiqihar, Heilongjiang } \\
\text { Civil Judgment } \\
\text { No. 587, Civil Appeal, (2010) }\end{array}$ \\
\hline $\begin{array}{l}\text { 2.Litigants } \\
\text { information }\end{array}$ & $\begin{array}{l}\text { Appellant (plaintiff in the court of first instance), Dai Wenlong, male. } \\
\text { Representative: Sun Fuyou, legal officer. } \\
\text { Appellant (defendant in the court of first instance), Tang Guohua, female. } \\
\text { Representative: Hu Guohua, legal officer. }\end{array}$ \\
\hline 3. The cause & Appellants Dai Wenlong and Tang Guohua disputed the settlement of assets on \\
\hline
\end{tabular}




\begin{tabular}{|c|c|}
\hline $\begin{array}{l}\text { of action, the } \\
\text { procedural } \\
\text { history and } \\
\text { summary of } \\
\text { parties' } \\
\text { complaints } \\
\text { and defenses }\end{array}$ & $\begin{array}{l}\text { separation. Both of them disagreed with Order No. 857, (2010) from the Nahe Court, } \\
\text { Heilongjiang. On their filing of their appeal there case was referred to a panel of the } \\
\text { Intermediate People's Court of Qiqihar, composed of Judge Liang Tiebin, Judge } \\
\text { Wang Youwei and Judge Li Yingli. Judge Liang acted as panel president. Clerk } \\
\text { Cheng Rihe recorded the court hearing. The procedure of this trial has been finalized. }\end{array}$ \\
\hline $\begin{array}{l}\text { Part Two: } \\
\text { Fact } \\
\text { (事实) } \\
\text { 1.Fact and }\end{array}$ & $\begin{array}{l}\text { The fact finding from the court of first instance indicated that the plaintiff and } \\
\text { defendant met in December, } 2008 \text { through friends. They cohabited on } 26 \text { April } 2009 \\
\text { without marriage. Dai gave Tang 110,000 RMB as a bride's gifts. Tang covered some } \\
\text { living expenses, loaned 50,000RMB to Dai's parents and paid 10,000RBM for her } \\
\text { three insurances (三金). Another 50,000 RMB still remains in Tang's account. } \\
\text { The plaintiff and defendant separated six months of cohabitation. Dai took legal } \\
\text { action against Tang claiming that Tang must refund the 60,000RMB to him. The } \\
\text { court of first instance ruled that according to section } 3 \text { of the Marriage Law of the } \\
\text { People's Republic of China and subsection } 1 \text { of Section } 10 \text { of the SPC's Judicial } \\
\text { Interpretation of the Marriage Law: Tong shall refund } 30,000 \mathrm{RMB} \text { to Dai. The } \\
\text { amount must be paid within } 7 \text { days from the first day of the judgment enforcement. } \\
\text { The legal cost is 1,300RMB. The Court reduced this cost to half. Tang was assigned } \\
\text { 340RMB in legal costs, and Dai, 310RMB in legal costs. }\end{array}$ \\
\hline & $\begin{array}{l}\text { Both Dai and Tang disagreed with this order and appealed to this court. They argued } \\
\text { that the judgment at the court of first-instance was inconsistent in law. } \\
\text { Dai argued that he gave Tang bride gifts totaling 110,000RBM and that Tang still had } \\
50,000 \mathrm{RMB} \text { left after she covered her living expenses. The three insurances and the } \\
50,000 \mathrm{RMB} \text { are still in Tang's possession. These assets should, therefore, be } \\
\text { refunded to Dai. } \\
\text { Tang argued that } 90,000 \mathrm{RMB} \text { is the bride's gift. As for the 10,000 RMB that was } \\
\text { paid to cover living expenses and three insurances, this was a gift from Dai and it } \\
\text { should not be refunded. Tang also covered some living expenses during cohabitation, } \\
\text { and these expenses should also not be refunded. }\end{array}$ \\
\hline $\begin{array}{l}\text { Part Three, } \\
\text { reasoning }\end{array}$ & $\begin{array}{l}\text { ne fact finding from the court of second instance clarified that Dai and Tang } \\
\text { habited without marriage. This relationship could not be protected by the Marriage } \\
\text { aw. However, the cohabitation relationship resulted in Dai giving the } 100,000 \mathrm{RMB}\end{array}$ \\
\hline
\end{tabular}




\begin{tabular}{|c|c|}
\hline & $\begin{array}{l}\text { to Tang as a bride's gift. Tang shall refund it. The Court also reaffirms that the } 10,000 \\
\text { insurance cost given as gift which shall not be refunded. Tang has the 50,000 RMB in } \\
\text { her account. The order of the court of first instance is appropriate. This court cannot } \\
\text { accept Dai and Tang's application. According to } 1.1 .153 \text { of the Civil Procedure Law, } \\
\text { it is ordered as below: }\end{array}$ \\
\hline $\begin{array}{l}\text { Part Four } \\
\text { Judgment } \\
\text { result } \\
\text { (判决结果) }\end{array}$ & Dismiss the appeal. \\
\hline $\begin{array}{l}\text { Part five } \\
\text { Conclusion } \\
\text { ( 尾部) } \\
\text { 1. the } \\
\text { allocation of } \\
\text { related costs }\end{array}$ & The legal cost 1,350 RMB, Dai bears 1,300, Tang 50. \\
\hline 2.clarification & This order is final. \\
\hline $\begin{array}{l}\text { 3.Panel and } \\
\text { court seal. }\end{array}$ & $\begin{array}{l}\text { Judgment Panel: Judge: Liang Tiebin, president of this panel. } \\
\text { Judge: Wang Youwei } \\
\text { Judge: Li Yingli } \\
\text { 14 December, } 2010 . \\
\text { Legal clerk: Cheng Rihe. }\end{array}$ \\
\hline
\end{tabular}

This second-instance reporting in a matter-of-fact and sparse manner indicated only basic details concerning the court personnel and litigants as well as the appropriateness of particular laws and a brief outline of the appellant arguments. ${ }^{74}$ The Court noted the lack of protection under the Marriage Law, but it nevertheless focused on the nature of a bride's gift. The court's 'open' reporting gave only a brief legal reasoning in Part 5, but this new reporting was still a step towards limited transparency; and it minimally supported a more uniform understanding throughout the country in an important area of conflicted law regarding the bride's gift. 
As for what is likely the most critical area of legal reasoning, the SPC aimed high, demanding that the judge analyze the validity of disputed evidence, authenticate the evidence, and state the specific reasoning supporting the evaluation of all of the evidence. The SPC formally required that the related process of judgment be made open to the public and that judgment, itself, was to be made transparent.

\section{Openness and the Process of Judgment Making}

The SPC has taken the lead on openness, but a cursory reference to on-line SPC publication of judicial reasoning suggests a fairly high degree of reluctant conservatism as to what is being made available. Also, possibly because of the lack of dedicated budget, the SPC only 'encourages,' but does not require open reporting of the judges' developed comments on their respective decisions.

The case of Mr. Zhao Ming vs. Shanxi Exploration Institute, over the validity of Mr. Zhao's provincial mining exploration permit, is illustrative of the political complexities that can easily interfere with transparency. Essentially, Mr. Zhao had paid for a licence fee, but his licence was suddenly revoked. The mining company took the provincial government to court for illegally revoking its licence. The online material was painfully vague and brief in its report in the 'Judgment Body' that includes fact finding, legal reasoning, the specified articles of law applied in the case and the final ruling. There was no public explanation of why the court favoured the Shanxi Exploration Institute's legal reasoning over that of Mr. Zhao. The SPC on-line judgment did not explain the decision-making process. ${ }^{75}$

A look at the context, however, suggests that the explanation for non-disclosure may lie in sensitive inner-system controversy over the law on secrecy. Due to the disagreement between the three SPC judges on the panel, the case had to be moved to the Judicial Committee of SPC. The panel was concerned that the case could have significant ramifications for public ownership of mineral resources. The SPC Judicial Committee had received a letter from the Shanxi government marked 'state secret' and subsequently decided in favour of the Province of Shanxi and its wholly owned agent, Shanxi Exploration Institute and then passed on its legal reasoning to the original panel. One can reasonably speculate that the SPC Judicial Committee was receptive to argument that a 
decision against the province would threaten the ownership of public assets. However, not all of the evidence, especially the confidential letter, was shared with the mining company.

Apparently, the SPC and the provincial government worked together to preserve public property; however, the on-line judgment preserved state secrecy and did not disclose the determining legal reasoning that was passed from the Judicial Committee to the panel. The still very loosely conceived laws on state secrets and state archiving are likely to inhibit a wider construction of transparent disclosure of legal reasoning in a system that has not clearly and precisely set out the legal definitions of property rights. The enhanced development of legal reasoning then faces a number of obstacles. China's essentially civil law tradition is biased in favour of the simple reporting of judgments. The Party has committed to transparency for important reasons of its own, but the Party has traditionally supported a strong approach to state secrecy, and judges generally cannot entertain proceedings involving state secrets.

While the public is now receiving unprecedented access to new information, the quality of this information remains at issue, and it is hard empirically to demonstrate at this early juncture the degree to which newly generated access will translate into greater public confidence in the legal system. However, the system is not naturally predisposed to reporting on itself and the reform legal community is likely to be disappointed in the low standard of circulated legal information.

Still in consideration of past preference for almost absolute non-disclosure, the published standard of judgment has definitely been enhanced in the SPC's recent efforts to publish all of its judicial interpretations. Openness is seen as highly desirable in that it supports the SPC plan for the nationwide consistency of court judgments. Despite the declared planning objectives of the SPC, there is still extraordinary unevenness in court decisions from place to place that reflects the pattern of local corruption, or 'local protectionism.' Local courts are now increasingly subject to interested review by local people's congress and local government for the most part still controls the budgetary lifelines of local courts.

The proliferation of wrongly judged cases, the uneven, and indeed, the irrational application of the centre's standards of justice amount to a 'regional and sectoral protectionism' that challenges the 
integrity of SPC and the provision of justice to the people. ${ }^{76}$ On the other side of the coin, there is concern lest the SPC become too paternalistic and too interventionist and smothers incipient and weak 'freedom of judge's decision-making' at the local levels.

This problem was already identified in Ronald Brown's early work on the court system:

Within the potentiality of 30 different judicial "fiefdoms" (some such as Sichuan with responsibility for over 100 million people), perhaps one can better understand the Chinese view of the usefulness of "socialist legal devises" such as adjudication supervision. Without adequate supervision by higher courts over lower, it is felt there could be even more "slippage" and lack of consistent and harmonized legal standards in the country. As meaningful centralized control is realized, perhaps the need for and use of adjudication supervision will wane. ${ }^{77}$

Brown had hoped that the SPC would extend the new law on judges and the process of professionalism in a balanced manner so as to support the competency of local judges while also 'cutting against the reported instances of unresponsiveness of courts and judges to meaningful law enforcement within their own courts.'

Brown was writing in 1997 and the above 'need' is now waxing rather than waning. In response to the need for uniform standards of judgment the $S P C$ has had to devise a new system that substitutes for the clarity and stability of a case law system. At least since 2002 the SPC was been working on a system of 'leading cases' (案件指导)that are to be published and circulated to judges throughout the lower level courts. Inner-SPC identification of leading cases starts with the study of available cases within the SPC's Research Office and its process of consultation with judges and leading experts in the system.

Although in formal terms these cases are for 'guidance' and they are not binding on judges' decision-making, in practical application the guidance is hard to ignore. Judges are now expected to take into account the leading cases when they make decisions. The degree and quality of transparency would seem to have contradictory implications. Too much transparency and the legal system suffers a loss of dignity. On the other hand, a carefully balanced transparency might create a positive pressure for better legal reasoning. The SPC's 'leading cases' may give the judges something to rely on as they are exposed to closer public scrutiny. The SPC encourage judges to write commentary on their judgments; for instance, the SPC set up a commentary template to 
encourage intellectual property judges to make comments on their own judgments. The SPC has published these commentaries to enhance popular understanding of the law on intellectual property.

Openness can be used to support a fair uniformity in the national justice system, and this article argues that current stage of openness reform in the judicial system is not a matter of a false start as in the past. In recent years the declaration of norms has been followed by new, if still qualified practice. However, the depth of the reporting on judgments still remains a practical issue of some consequence. The blinds in the 'darkroom' of judicial judgment have been left partially open, but there is still the question of how much sunshine is to be allowed in the court room.

Public reporting of judgments has been condensed. Arguably, this might be consistent with the Civil Law tradition as well as with the original mass-line populism. Much of the latest round of transparency reform has been initiated under the Court Presidency of Wang Shengjun. This agenda has included increasing focus on enhancing legal reasoning and on providing court judgments on court websites. Addressing provincial level judges Court President Wang Shengjun, however, insisted that the SPC would in 2011 reduce its meetings and documents by one third, and drawing on mass line understandings he targeted "pure formalism" throughout the court system. ${ }^{78}$ Wang advised the courts to keep only records that might have a bearing on future cases.

\section{Conclusion: A New Prospect for Judicial Transparency?}

Is there a new prospect for judicial transparency? There is still a much too limited scholarship in this area to establish a definitive pattern in practice. The above discussion is only suggestive, particularly as only part of the court system has been able to honor SPC instruction to establish internet reporting, and this reporting and its impact has yet to be comprehensively studied in all of its detail. It is important to note that the SPC has put in place a new generation of regulation, but the data regarding transparency is preliminary; and the current status of legal reasoning is unclear and needs much more research.

At the same time, scholars like Randall Peerenboom and Zhu Suli have drawn our attention to the methodological tendency of related Western study on judicial independence towards 'one size fits all' and they have suggested a more 'nuanced' approach. Indeed, in 2009 China's judges reviewed 
more than ten million cases. ${ }^{79}$ It is easy to criticize Chinese legal reform from the outside when you do not have responsibility for working out the myriad problems confronting such a mega-sized legal system as its deals with the complexities of history, culture, the pressures of modernization and the changing tensions between mass line populism and professionalism.

The above analysis notes that there are genuine reform imperatives in China that have placed transparency on the political agenda not only as a solution to corruption but as the basis of new governance or 'open public administration' in the contemporary information age. There has since 2007 been increasing reference to the Party-led 'political-legal system', but at the same time the SPC has moved ahead quickly with a new set of initiatives for internet reporting of court cases. The issue of the quality of this reporting is ongoing, but there is new initiative that is more qualitative in comparison with past initiatives for open trial.

Initially, progress towards open trial was fitful and desultory. After a sequence of declaratory commitments and after rapid court building and telescoped professionalization, a new generation of SPC regulation is fleshing out the declaratory law. In practice transparency reform is still qualified in favor of non-disclosure, but its very existence is marked in relation to past standards of exclusive judicial non-disclosure. Even in the context of warning against Western-style judicial independence, the SPC has helped establish a new benchmark for judicial transparency.

As Liebman and Wu have, with careful scholarly qualification, suggested the internet is creating new and exciting possibilities for judicial transparency in China and given the fast relation between politics and law, it is likely to have a greater impact in China than in the US or Europe. However, there is still the outstanding question as to what extent the "political'-legal system can tolerate transparency. China is thought to have a complete legal system, but it is still not complete. Judicial interpretation is still necessary to plug the holes in the system, and legal reasoning requires time to develop. The legal system is very new. Judicial professionalism is new and conflicted. There are a lot of holes and conflicting requirements in the law. The system does not yet enjoy the benefit of a cumulative generational wisdom that supports legal reasoning and with new media pressure and related Party interest judges may fall victim to 'cascading' information from the public. 
Professionalism is incipient. The courts and, especially lawyers, have had to endure outrageous political attacks for many years. Traditional culture and vested bureaucratic interests militate against disclosure. Officials and judges will weigh their career options as they consider whether disclosure or non-disclosure is more safe and which is more likely to produce a 'harmonious society'(和谐社 会). Official policy states 'disclosure is basic, non-disclosure is the exception'(公开为原则、不公开 为例外), but is there sufficient human capability and consciousness to support a critical regime change in favor of disclosure as opposed to non-disclosure?

As suggested in the above analysis one of the critical aspects of open trial reform that requires special attention is the public reporting of legal reasoning. Liebman and $\mathrm{Wu}$ argue that new 'horizontal' reference to like cases can facilitate a system that lacks precedence and needs to instill public confidence. What is more one should not underestimate the organizational capabilities of the Chinese political system. When there is political will, it can concentrate enormous administrative energies and move ahead rather quickly.

Detailed public reporting may expose the professional weaknesses of the system and if so public disaffection might undercut further commitment to transparency. Cautious authorities who are especially fixed on political stability are more likely to prefer a political balancing act rather than a cold water plunge into unqualified transparency. However, the implications of Hu Jintao's argument that China needs a modern governance and public administration that effectively 'opens channels of communication' as society undergoes profound changes and tensions, is surely worth examining.

Culture persists, but then so does the Party and so does reform. Court President Wang has put the court system on alert to rising social conflict especially in the areas of labor disputes, and tensions over housing loans and prices as well as housing demolitions. ${ }^{80}$ The judicial system is being urged to address the mounting problems of society and the economy. Post-SARS reform, for example, suggests that a repeat of the SARS scandal is less likely. The current focus on transparency exists because it might possibly assist in dealing with the imbalances in society that are highlighted in Hu's 'scientific development concept' and his approach to transparent public administration. 
Although the Party specifically resists the basic assumptions of Western liberal democracy and has yet to be convinced of the benefits of opposition generated by a multiple Party system, there is, with more on-line court transparency, potential to improve upon the development of the legal consciousness of the general population and the legal community, itself. Indeed, there is the possibility that more transparency will support a more robust citizenship than what was originally intended by the mass line. Judicial transparency has been endorsed because open communications in the new information age are seen as appropriate to citizen participation in modern public administration and as it supports at least some potential remedy as against the mounting contradictions in society and regime-destroying corruption. The 2010 white paper reflected mass line honesty, conceding that there are still problems, but it also claimed progress noting that between 2003 and 2010 the rate of citizen satisfaction with the work of building clean government had rose steadily from 51.9 to 70.6 per cent. ${ }^{81}$ Keeping in mind all of these conflicting considerations, above, the Party leadership seems favour a 'thin' transparency, or a 'transparency with Chinese characteristics.'

\footnotetext{
${ }^{1}$ For commentary on this citation see Hon T.S. Ellis, III, Sealing, judicial transparency and judicial independence, Villanova Law Review, vol. 53, 2008: 939-950. Rex v. Sussex Justices, 1 K.B. 256, 259(1924).

${ }^{2} \mathrm{Hu}$ Jintao, Hold high the great banner of socialism with Chinese characteristics and strive for new cictories in building a moderately prosperous society in all respects, Documents of the $17^{\text {th }}$ National Congress of the Communist Party of China, Beijing: Foreign Languages Press, 41.

${ }^{3}$ As discussed in Benjamin Liebman, China's courts: Restricted reform, The China Quarterly, no. 191, September 2007: 628 , fn 24.

${ }^{4}$ By way of example, refer to Benjamin L. Liebman, China's courts: Restricted reform, The China Quarterly, no. 191, September 2007, 620-38; Sida Liu, Beyond global convergence: Conflicts of legitimacy in a Chinese lower court, Law and Social Inquiry, 2006: 75-106; Zhang Qianfan, The people's court in transition: The prospects of the Chinese judicial reform, Journal of Contemporary China 12 (34), 2003: 69-101; Randall Peerenboom, Judicial accountability and judicial independence: An empirical study of individual case supervision in the People's Republic of China, The China Journal, vol. 55, 2006:67-92; Carl Minzer, Judicial disciplinary systems for incorrectly decided cases", in Margaret Woo and Mary Gallagher et al. eds., Chinese Justice: Civil Dispute Resolution in Contemporary China, Cambridge: Harvard University Press, 2011, 58-90; Xin He, Ideology or reality? Limited judicial independence in contemporary China, Australian Journal of Asian Law, No. 6, December 2004, 214-30; Susan Trevaskes, Political ideology, the Party, and politicking: Justice system reform in China, Modern China, 37 (3), 2011: 315-44..

${ }^{5}$ Sarah Biddulph, Through a glass darkly: China, transparency and the WTO, Asian Law, Vol. 3, 2001: 62.

${ }^{6}$ Transparency International, Corruption Perceptions Index 2010 Results, electronic copy available at: http://www.transparency.org/policy_research/surveys_indices/cpi/2010/results, accessed on 19 January 2011.

${ }^{7}$ For example, Jean-Pierre Cabestan, Director, French Centre for Research on Contemporary China, doubts the
} 
possibility of creating true judicial independence in China and disagrees with Randall Peerenboom's notion of a 'thin rule of law' without first abolishing the political supremacy of the CCP. See Jean-Pierre Cabastan, The political and practical obstacles to the reform of the judiciary and the establishment of a rule of law in China, Journal of Chinese Political Science, vol. 10, no. 1, April, 2005: 43.

8

${ }^{9}$ Anne Barrowclough, Australian Prime Minister Kevin Rudd Attacks China over Rio Tinto Trial, The Sunday Times, 30 March, 2010.

${ }^{10}$ Wang Shengjun zai quanguo zhengfa gongzuo dianshi dianhua huiyi shang qiangdiao: shizhong jianchi 'sange zhishang'gongzuozhidaosixiang nuli shixian renminfayuan gongzuo xin fazhan (Wang Shengjun stressed in a national television and radio conference on political and legal affairs, the consistency of the three supremes as our guiding work principle in achieving the new development of the people's courts), Guangming Ribao, 19 December 2009, 2.

${ }^{11}$ Zhu Suli, Political parties in China's judiciary, Duke Journal of Comparative and International Law, vol. 17, 2006, 535, 540.

${ }^{12}$ Randall Peerenboom, ed., Introduction, Judicial Independence in China: Lessons for Global Rule of Law Promotion, Cambridge, New York: Cambridge University Press, 2010, 1.

${ }^{13}$ Randall Peerenboom, ed., Judicial independence in China: Common myths and unfounded Assumptions, Judicial Independence in China, 70-71.

${ }^{14}$ Zhang Yan \& Wang Jingqiong, Rising tide of foreign litigants in civil cases, China Daily, 18 December 2010, 2.

${ }^{15}$ Donald Clarke, Introduction: The Chinese legal system since 1995: Steady development an striking continuities, The China Quarterly, no. 191, September 2007: 558; Benjamin Liebman and Tim Wu, China's network justice, Chicago Journal of International Law, Summer 2007, 8 (1):260.

${ }^{16}$ Liebman and $\mathrm{Wu}, 319$.

${ }^{17}$ Liebman and $\mathrm{Wu}, 265$.

${ }^{18}$ Liebman and $\mathrm{Wu}, 267$.

${ }^{19}$ Jean-Pierre Cabestan, The political and practical obstacles to the reform of the judiciary, 52.

${ }^{20}$ Fan Wu, Legal reasoning in Chinese and Swiss appellate judgments - Exploring China's path towards the rule of law, Tsinghua China Law Review, Vol. 2, (2009).

${ }^{21}$ According to the authors' discussion with Professor Wang Xixin.

${ }^{22}$ Discussion with Wang Xixin, Director, Centre for Governance and Public Law, Peking University, December 2010.

${ }^{23}$ See Ronald C. Keith on comparative legal cultures, China Struggle for The Rule of Law, New York: St. Martin's Press, 1994, 43-48.

${ }^{24}$ See Xin Ren, Tradition of the Law and Law of the Tradition: Law, State and Social Control in China. Westport, CT and London: Greenwood Press, 10. Geoffrey MacCormack also makes the key additional point that the 'Confucianization of the law' allowed the judge and ruler to draw directly on their own morality 'in dealing with situations for which there is no legal rule exactly to the point.' Geoffrey MacCormack, Traditional Chinese Penal Law. Edinburgh: Edinburgh University Press, 1990, 38 as discussed in Keith and Lin, New Crime in China. London: Routledge, 2006: 8-9.

${ }^{25}$ Stuart Schram, The Thought of Mao Zedong, Cambridge: Cambridge University Press, 1989, 86.

${ }^{26}$ See On the mass line, Stuart Schram, ed., The Political Thought of Mao Tse-tung, rev. edition, New York: Praeger Publishers, 1977, 317.

${ }^{27}$ See On Learning from one's subordinates, Schram, ed., The Political Thought, 319.

${ }^{28}$ Jiang Zemin, Jiang Zemin On the 'Three Represents', 133.

${ }^{29}$ Information Office, State Council, China's efforts to combat corruption and build a clean government, Document, China Daily, 30 December 2010, 10.

${ }^{30}$ China's efforts to combat corruption and build a clean government, 10 . 
${ }^{31}$ Long Fei \& Zhao Xi, Guandian: 'Xin Zhongguo sifa gongkai de lishi mailuo (Viewpoint: The historical background of the judicial transparency in new China). Zhongguo shenpan, (China trial), Issue 51, (5 May, 2010), 16.

${ }^{32}$ The $15^{\text {th }}$ National Congress of the Communist Party of China held from September $12-18,1997$ in Beijing.

${ }^{33}$ Top Chinese judge stresses judicial openness, Xinhua News Agency-CEIS, 15 July 1998, 1.

34 :Transparency in the judiciary, Beijing Review, Vol. 47, No. 18, 6 May 2004.

35 . Long Fei \& Zhao Xi, Guandian: Xin Zhongguo sifa gongkai de lishi mailuo (Viewpoint: The historical background of the judicial transparency in new China). Zhongguo shenpan, (China trial), Issue 51, 5 May, 2010, 16.

${ }^{36}$ Ibid, 16.

${ }^{37}$ Ronald C Keith and Zhiqiu Lin, Sars in Chinese law and politics, China Information. 21(3), 2007: 403-24.

${ }^{38}$ CPC Central Committee decision on enhancing the Party's ability to govern, 24 September 2004, NewsEdge Document No.a 200410041477.1_9d5b1b9fd4e2f3fe.

${ }^{39}$ Section X, Building of political democracy in China at http://english.peopledaily.com.cn/whitepaper/democracy/democracy(10).html, accessed on 14April 2011.

${ }^{40} \mathrm{Hu}$ Jintao, Hold high the Great Banner of Socialism with Chinese Characteristics and Strive for New Victories, 37

${ }^{41}$ Ibid, 41, authors' own italics.

${ }^{42}$ He Weifang,Panjueshu shangwang nanzai he chu( Why it is so difficult to put the judgments online), Fazhi ribao, (Legal daily) ,15 December, 2005.

${ }^{43} \mathrm{Hu}$ Xiabing, "Yixing de kandai panjueshu shangwang (A reasonable look at judgment on the internet)". Fazhi ribao, (Legal daily), 5 January, 2006.

${ }^{4}$ Ibid.

${ }^{45}$ See Ling Li, Corruption in China's Courts, Judicial Independence in China, Lessons for Global Rule of Law Promotion, edited by Randall Peerenboom, Cambridge, New York: Cambridge University Press, 2010, 201-202, the number of court personnel investigated in 2006 for corruption in just five provinces(out of 32 provincial level administrative regions) is 585.

${ }^{46}$ See Benjamin Liebman, China’s Courts: Restricted Reform, The China Quarterly, 191, September 2007, pp. 620-638.

${ }^{47}$ Long Fei \& Zhao Xi, Guandian: 'Xin Zhongguo sifa gongkai de lishi mailuo, (Viewpoint: The historical background of the judicial transparency in new China), Zhongguo shenpan, (China trial), Issue 51, 5 May, 2010, 16.

48 Shumei Hou \& Ronald Keith, The Defense Lawyer in the Scales of Chinese Criminal Justice, Journal of Contemporary China, July, 2011.

${ }^{49}$ Fan Wu, Legal reasoning in Chinese and Swiss appellate judgments-Exploring China's path towards the rule of law, electronic copy available at: http://ssrn.com/abstract=1412546, accessed on 12 December, 2010.

${ }^{50}$ See Section 5 of The Six Requirements of Open Justice.

51 Wim Voermans, Judicial transparency furthering public accountability for new judiciaries, http://www.utrechtlawreview.org/Volume 3, Issue 1 (June) 2007, 150.

${ }^{52}$ Long Fei \& Zhao Xi, Guandian: Gedi fayuan sifa gongkai zhi tansuo yu shijian( Exploring and practicing Judicial openness in all the local courts), Zhongguo shenpan, (China trial), Issue 51, (May 5, 2010).

${ }^{53}$ See Henan People's Court Website, available at: http://hnfy.chinacourt.org/public/detailWs.php?id=108850, accessed on 30 December 2010.

${ }^{54} \mathrm{Su}$ Yongtong, Bu an 'fali' Chupai de gaoyuan yuanzhang, (The High Court's President did not follow 'the rules' to play the game), Nanfang zhoubao, (South Weekend), 18 February 2010.

${ }^{55}$ Long Fei \& Zhao Xi, op. cit., 14. The detail concerning the numbers for the different courts can be found on the SPC Chinese website, http://www.court.gov.cn/jgsz/rmfyij/ Cases involving foreigners normally in the first instance pass through the Intermediate Courts, but in civil and administrative law where comparatively high amounts of assets and funds are involved, or where a significantly new element of law is involved cases can be taken up at the Higher and even at the People's Supreme Court level. 
${ }^{56}$ Pingdingshan Court Website News: Pingdingshan zhongyuan jiu Shi Jianfeng zhapian yi'an zhaokai xinwen fabuhui (Pingdingshan Intermediate Court holds media conference on the Shi Jianfeng fraud case), available at: http://pdszy.chinacourt.org/public/detail.php?id=535, accessed on $18^{\text {th }}$ January, 2011.

${ }^{57}$ Henan High Court Website News: Pingdingshan Shi Jianfeng anjian jinzhan he zhuize qingkuang fabu( Pingdingshan Shi Jianfeng case progress and calling to account those responsible ), available at: http://hnfy.chinacourt.org/public/detail.php?id=110137, accessed on $19^{\text {th }}$ January 2011.

58 Ibid.

${ }^{59}$ Chinalawinfo is Chinese law database that established by Peking University. It provides information related to laws, regulations, legal documents and leading cases.

${ }^{60}$ This document is available at: http://vip.chinalawinfo.com/newlaw2002/slc/slc.asp? $\mathrm{db}=\mathrm{chl} \&$ gid=139318, accessed on $30^{\text {th }}$ December 2010.

${ }^{61}$ Huang Honglian, Quanguo 100 ge fayuan sifa gongkai shifanyuan,( Across the country 100 courts became standard model courts for openness), available at: http://hzrb.hangzhou.com.cn/law/system/2010/10/21/011006271.shtml, accessed on $20^{\text {th }}$ December, 2010.

62 This number can be found on the SPC Chinese website, http://www.court.gov.cn/jgsz/rmfyjj/

${ }^{63}$ Hang Yong, Henan gaoyuan qiangxing tuixing panjueshu shangwang shesu anjian xiajiang (Henan High Court enforced the judgments online and the rate of lawsuit was reduced), <http://www.chinanews.com.cn/gn/news/2009/1104/1946601.shtml, accessed on $20^{\text {th }}$ December, 2010.

${ }^{64}$ Nanping Liu and Michelle Xiao Liu, Trick or Treat: Legal Reasoning in the Shadow of corruption in the People's Republic of China, N.C.J. INT'L. L\& Com. REG. XXXIV, 2009, pp. 179-261.

${ }^{65}$ Ibid.

${ }^{66}$ Ibid., p. 186.

${ }^{67}$ Ibid., p. 185, p. 222.

${ }^{68}$ Authors discussions with a senior judge at the SPC.

${ }^{69}$ Fan Wu, Legal reasoning in Chinese and Swiss appellate judgments.

${ }^{70}$ Ibid.

${ }^{71}$ Nanping Liu and Michelle Xiao Liu, Trick or Treat: Legal Reasoning in the Shadow of corruption in the People's Republic of China, N.C.J. INT'L. L \& Com. REG. XXXIV, 2009, pp. 179-261.

72 Ibid.

${ }^{73}$ This judgment in Chinese can be found at website of Qiqihar Intermediate People's Court, Heilongjiang sheng Qiqihar shi zhongji renmin fayuan minshi panjueshu,(2010) Qimin yizhongzi 587 hao, accessed at:

http://www.qqhrfy.gov.cn/mana/News_cpws.asp?NewsID=261

${ }^{74}$ The brevity of this document might be compared to more extended first-instance reporting of a basic level Shanxi district court on unlawful occupation of land and unlawful assembly disrupting public communications. For the full text of the Shanxi Linfen Yaodu District People's Court Criminal Judgment (2009) YXCZ no. 654 in Chinese Law and Religion Monitor, vol. 6, 2010:75-100.

${ }^{75}$ Authors' discussion with a China law scholar.

${ }^{76}$ Li Buyun, Constitutionalism in China, (Xianzheng yu Zhongguo). Beijing: Law Press, 2006.

${ }^{77}$ Ronald Brown, Understanding Chinese courts and legal process: Law with Chinese characteristics, Boston: Kluwer Law International, 145. For further updated analysis see Ronald C. Keith, Zhiqiu Lin and Houshu Mei, China's Supreme People's Court and the Struggle for the Rule of Law, Routledge, U.K., forthcoming

${ }^{78}$ Fewer Meetings and Fewer Documents, China Daily, (21 December 2010), 4. Mao used to complain of 'three toomanys', 'too many officials, too many meetings and too many documents'. 
${ }^{80}$ Social conflict is on the rise, Says top judge, China Daily, 21 December 2010.

${ }^{81}$ Information Office, State Council, China's efforts to combat corruption and build a clean government, in China Daily, 30 December 2010, Document, 9.

\section{References}

Biddulph, Sarah, (2001)Through a glass darkly: China, transparency and the WTO, Asian Law, Vol. 3, 2: 59-95..

Brown, Ronald, (1997) Understanding Chinese Courts and Legal Process: Law with Chinese characteristics, Boston: Kluwer Law International.

Cabastan, Jean-Pierre, (2005) The political and practical obstacles to the reform of the judiciary and the establishment of a rule of law in China, Journal of Chinese Political Science, vol. 10, no. 1, 43-64.

Chinese Communist Party, (2007), Documents of the $17^{\text {th }}$ Congress of the Communist Party of China. Beijing: Foreign Languages Press.

Chinese Communist Party (2004), CPC Central Committee decision on enhancing the Party's ability to govern, 24 September 2004, NewsEdge Document No.a 200410041477.1_9d5b1b9fd4e2f3fe

Clarke, Donald, (2007)The Chinese Legal System Since 1995, The China Quarterly, special issue, no. 191.

Ellis, Hon. T.S., (2008) Sealing, judicial transparency and judicial independence, Villanova Law review, vol. 53, 939950.

Hang Yong, (2010), Henan gaoyuan qiangxing tuixing panjueshu shangwang shesu anjian xiajiang (Henan High Court enforced the judgments online and the rate of lawsuit was reduced), <http://www.chinanews.com.cn/gn/news/2009/11 04/1946601.shtml, accessed on $20^{\text {th }}$ December.

He Weifang,(2005), Panjueshu shangwang nanzai he chu( Why it is so difficult to put the judgments online), Fazhi ribao, (Legal daily) ,15 December.

Hu Xiabing, (2006), Yixing de kandai panjueshu shangwang (A reasonable look at judgment on the internet). Fazhi ribao, (Legal daily), 5 JanuarY.

Huang Honglian, (2010), Quanguo 100 ge fayuan sifa gongkai shifanyuan,( Across the country 100 courts became standard model courts for openness), available at: http://hzrb.hangzhou.com.cn/law/system/2010/10/21/011006271.shtml, accessed on $20^{\text {th }}$ December.

Jiang Zemin, Jiang Zemin On the 'Three Represents'. Beijing: Foreign Languages Press.

Keith, Ronald C., (1904) China's Struggle for the Rule of Law. New York: St. Martin's Press.

Keith, Ronald C. and Lin, Zhiqiu Sars in Chinese law and politics, China Information. 21(3), 2007: 403-24.

Keith, Ronald C. and Lin, Zhiqiu, (2006) New Crime in China: Public Order and Human Rights. London and New York: Routledge.

Fan $\mathrm{Wu}$, (2009) Legal reasoning in Chinese and Swiss appellate judgments - Exploring China's path towards the rule of law, Tsinghua China Law Review, Vol. 2.

Huang Honglian, (2010) Quanguo 100 ge fayuan sifa gongkai shifanyuan,( Across the country 100 courts became standard model courts for openness), available at: http://hzrb.hangzhou.com.cn/law/system/2010/10/21/011006271.shtml, accessed on $20^{\text {th }}$ December, 2010.

Li, Buyun, (2006) Constitutionalism in China, (Xianzheng yu Zhongguo). Beijing: Law Press.

Liebman, Benjamin L. (2007) China's courts: Restricted reform, The China Quarterly, no. 191: 620-38

Liebman, Benjamin L. and Wu, Tim, (2007), China's network justice, Chicago Journal of International Law, 8 (1): $257-$ 320.

Liu, Sida,(2006), Beyond global convergence: Conflicts of legitimacy in a Chinese lower court, Law and Social Inquiry, 2006: 75-106 
Long Fei \& Zhao Xi, (2010), Guandian: Xin Zhongguo sifa gongkai de lishi mailuo, (Viewpoint: The historical background of the judicial transparency in new China), Zhongguo shenpan, (China trial), Issue 51: 16

Long Fei \& Zhao Xi, (2010), Guandian: Gedi fayuan sifa gongkai zhi tansuo yu shijian( Exploring and practicing Judicial openness in all the local courts), Zhongguo shenpan, (China trial), Issue 51, May 5, 2010

MacCormack, Geoffrey (1990), Traditional Chinese Penal Law. Edinburgh: Edinburgh University Press.

Carl Minzer, (2011), Judicial disciplinary systems for incorrectly decided cases, in Margaret Woo and Mary Gallagher et al. eds., Chinese Justice: Civil Dispute Resolution in Contemporary China, Cambridge: Harvard University Press, 58-90. Nanping Liu (2009) and Michelle Xiao Liu, Trick or Treat: Legal Reasoning in the Shadow of corruption in the People's Republic of China, N.C.J. INT'L. L\& Com. REG. XXXIV, 179-261.

Pingdingshan Court Website News (2011) Pingdingshan zhongyuan jiu Shi Jianfeng zhapian yi'an zhaokai xinwen fabuhui (Pingdingshan Intermediate Court holds media conference on the Shi Jianfeng fraud case), available at: http://pdszy.chinacourt.org/public/detail.php?id=535, accessed on $18^{\text {th }}$ January, 2011.

Randall Peerenboom, ed., (2010) Judicial Independence in China: Lessons for Global Rule of Law Promotion, Cambridge, New York: Cambridge University Press.

Randall Peerenboom, (2006) Judicial accountability and judicial independence: An empirical study of individual case supervision in the People's Republic of China, The China Journal, vol. 55, 2006:67-92.

Qiqihar Intermediate People's Court, (2010) Heilongjiang sheng Qiqihar shi zhongji renmin fayuan minshi panjueshu, Qimin yizhongzi 587 hao, accessed at http://www.qqhrfy.gov.cn/mana/News_cpws.asp?NewsID=261

Shanxi Linfen Yaodu District People's Court Criminal Judgment (2009) YXCZ no. 654 in Chinese Law and Religion Monitor, vol. 6:75-100.

Schram, Stuart R., ed., (1977), The Political Thought of Mao Tse-tung, rev. edition, New York: Praeger Publishers.

Shumei Hou \& Ronald Keith, The Defense Lawyer in the Scales of Chinese Criminal Justice, Journal of Contemporary China, July, 2011.

State Council, Information Office, (2010), China's efforts to combat corruption and build a clean government, in China Daily, 30 December 2010, Document, 9.

State Council, Information Office, (2005), Building of political democracy in China at

http://english.peopledaily.com.cn/whitepaper/democracy/democracy(10).html, accessed on 14April 2011.

Su Yongtong, (2010), Bu an 'fali' Chupai de gaoyuan yuanzhang, (The High Court's President did not follow 'the rules' to play the game), Nanfang zhoubao, (South Weekend), 18 February 2010

Trevaskes, Susan, (2011), Political ideology, the Party, and politicking: Justice system reform in China, Modern China, 37 (3): 315-44

Voermans, Wim, Judicial transparency furthering public accountability for new judiciaries, http://www.utrechtlawreview.org/Volume 3, Issue 1 (June) 2007

Xin He, (2004), Ideology or reality? Limited judicial independence in contemporary China, Australian Journal of Asian Law, No. 6, December 2004, 214-30

Xin Ren, Tradition of the Law and Law of the Tradition: Law, State and Social Control in China. Westport, CT and London: Greenwood Press.

Zhang Qianfan, (2003), The people's court in transition: The prospects of the Chinese judicial reform, Journal of Contemporary China 12 (34): 69-101

Zhu Suli, (2006), Political parties in China’s judiciary, Duke Journal of Comparative and International Law: 533-60. 